\title{
Differences in Hemoglobin Levels in Pregnant Women through Multi-Micronutrient Supplements and Iron Tablets
}

\author{
Jamaludin Sakung ${ }^{1}$, Dewi Tosae ${ }^{2}$, Gunarmi $^{2}$, Andi Imam Arundhana*j \\ ${ }^{1}$ Department of Health Biochemistry, Faculty of Teacher Training and Education, Tadulako University, Palu, Indonesia; \\ ${ }^{2}$ Department of Midwifery, STIKES Guna Bangsa Yogyakarta, Depok, Indonesia; ${ }^{3}$ Department of Nutrition, School of Public \\ Health, Hasanuddin University, Makassar, Indonesia
}

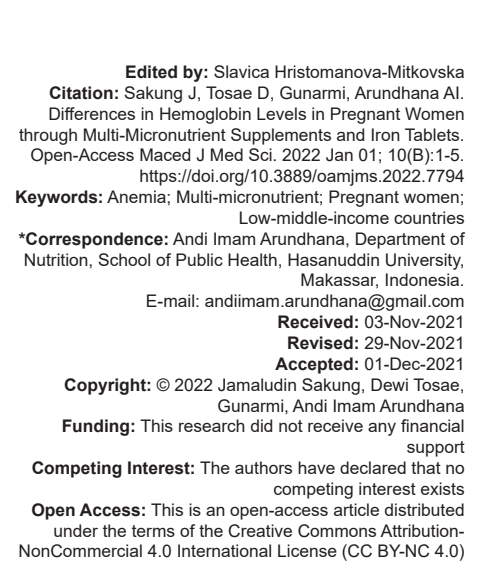

Abstract

BACKGROUND: A high incidence of anemia, particularly severe anemia, among pregnant women has been a major cause of maternal mortality worldwide. Multi-micronutrient supplement (MMS) has been beneficial for health outcomes.

AIM: The study was aimed to examine the effect of MMS compared to iron-folic acid supplement (IFA) on hemoglobin $(\mathrm{Hb})$ levels among pregnant women.

METHODS: The study was a quasi-experiment with a three-group pre-post-test design, namely, IFA group, MMS group, and MMS + IFA group. A total of 120 participants enrolled were divided equally in each group. The statistical analysis performed was paired t-test and one-way ANOVA using SPSS.

RESULTS: The study result shows that there was a significant difference in the $\mathrm{Hb}$ levels of pregnant women after the intervention in all groups $(p<0.001)$. The highest increase in $\mathrm{Hb}$ levels was in the IFA + MMS combining group by $1.1 \mathrm{~g} / \mathrm{dL}$ of $\mathrm{Hb}$ followed by MMS and IFA $(0.8 \pm 0.37$ and $0.4 \pm 0.31$, respectively).

CONCLUSION: The combination of Fe and MMS groups could increase Hb levels compared to IFA. Thus, replacing IFA with MMS is reasonably in preventing anemia among pregnant women.

\section{Introduction}

A healthy pregnancy is one of the goals of health development programs in Indonesia. Some physiological changes that occur in pregnant women can cause serious consequences and threats to the health of the pregnancy. Physically, pregnant women will feel tired, weak, and lethargic, meaning that they will need to depend on the people around them. The level of awareness of maintaining good health during pregnancy is one of the most important factors affecting the maternal mortality rate (MMR) during the process of pregnancy and childbirth [1], [2].

Maternal mortality is an important indicator that needs to be considered in determining the degree of health in the community. This rate refers to the death of a woman during pregnancy or within 42 days after delivery from causes directly or indirectly related to childbirth. Maternal mortality rates continue to increase every year. Globally, the number of maternal deaths due to pregnancy complications and labor process is approximately $289,000 /$ year, which is equal to 800 women per day. Global data show that Indonesia has the highest maternal mortality rate in Southeast Asia with an estimation of 11,534 deaths/year. One of the risk factors that may cause maternal death is anemia during pregnancy [3], [4], [5].

Anemia during pregnancy can cause multiple negative implications for mothers' health, including bleeding during labor. Bleeding is the main cause of high maternal mortality (HMM) in Indonesia, indicating that anemia in pregnancy might be prevalent among Indonesian population. The prevalence of anemia in pregnant women is $14 \%$ in developed countries and $51 \%$ in developing countries. It is estimated that 90,000 deaths are caused by anemia per year. The incidence of anemia in Africa, Southeast Asia, and the Western Pacific region is very high, with more than $90 \%$ of the population found to be anemic in surveys conducted with children and mothers, especially pregnant women [6].

Iron deficiency anemia is a condition that often occurs in pregnant women. It can cause various dysfunctions including a decrease in endurance, and late growth and development of the fetus. Therefore, this problem requires proper handling and prevention. Giving iron supplements and multi-micronutrient 
supplements (MMS) to pregnant women are one of the health measures that can assist with anemia.

Taking iron supplements such as MMS and Fe tablets during pregnancy can reduce the risk of babies being born with low body weight and anemia. Meeting iron needs during pregnancy can also boost the immune system and prevent anemia in pregnant women. MMS and Fe tablets during pregnancy help with the synthesis of erythrocytes, which play a role in preventing fatigue during pregnancy, and can ensure that pregnant women's hemoglobin $(\mathrm{Hb})$ levels become normal. If pregnant women do not take MMS and Fe tablets during pregnancy, they will be prone to anemia and will quickly tire. A non-governmental organization (NGO) is introducing a MMS for pregnant women, which is replacing Fe tablets with MVA. Understanding the effectiveness of MMS and Fe tablets is expected to help prevent anemia in pregnant women.

\section{Materials and Methods}

This research is a quantitative study, the research design used is a quasi-experiment with the approach of three groups, pre- and post-test design. A total of 120 pregnant women were divided into two groups, Group 1 (Fe tablet supplements) and Group 2 (MMS supplements), and Group 3 (a combination of Fe tablets and MMS). Study participants were selected using proportional random sampling.

A HemoCue, blood $\mathrm{Hb}$ monitoring system designed for quantitative measurement of blood $\mathrm{Hb}$ levels, was used to measure $\mathrm{Hb}$ value of participants. Trained research team performed taking bloods to measure the women's $\mathrm{Hb}$.

This bivariate analysis is used to look at differences in $\mathrm{Hb}$ levels in pregnant before and after the giving of Fe tablets, vitamin angel, and a combination of Fe tablets + MMS. The statistical test used is a paired t-test used to test the comparative hypothesis of one unpaired sample. One-way ANOVA test is to determine the effect of MMS on $\mathrm{Hb}$ levels. All statistical analyses were performed using SPSS version 22.

\section{Results}

Majority of participant' characteristics were $84.2 \%$ aged $20-35$ years, $44.2 \%$ were graduated elementary school, $80 \%$ as a housewife, and $54.2 \%$ had normal $\mathrm{Hb}$ level (Table 1).

Based on the age group, the $\mathrm{Hb}$ level in participants aged under 20 and over 35 had the highest
Table 1: Characteristics of subjects based on intervention groups

\begin{tabular}{|c|c|c|c|c|}
\hline \multirow[t]{3}{*}{ Characteristic } & \multicolumn{4}{|l|}{ Groups } \\
\hline & Fe tablets & MMS & Fe tablets+MMS & Total \\
\hline & $\mathrm{n}(\%)$ & $n(\%)$ & $\mathrm{n}(\%)$ & $n(\%)$ \\
\hline \multicolumn{5}{|l|}{ Age group $<20$ and } \\
\hline$>35$ years (risk) & $6(15.0)$ & $3(7.5)$ & $10(25.0)$ & $19(15.8)$ \\
\hline $20-35$ years (not risk) & $34(85.0)$ & $37(92.5)$ & $30(75.0)$ & $101(84.2)$ \\
\hline \multicolumn{5}{|l|}{ Education level } \\
\hline Elementary school & $23(57.5)$ & $13(32.5)$ & $17(42.5)$ & $53(44.2)$ \\
\hline Secondary school & $7(17.5)$ & $5(12.5)$ & $12(30.0)$ & $24(20.0)$ \\
\hline Tertiary school & $8(20.0)$ & $13(32.5)$ & $9(22.5)$ & $30(25.0)$ \\
\hline Bachelors' degree & $2(5.0)$ & $9(22.5)$ & $2(5.0)$ & $13(10.8)$ \\
\hline \multicolumn{5}{|l|}{ Occupation status } \\
\hline Housewife & $39(97.5)$ & $24(60.0)$ & $33(82.5)$ & $96(80.0)$ \\
\hline Government staff & $1(2.5)$ & $16(40.0)$ & $7(17.5)$ & $24(20.0)$ \\
\hline \multicolumn{5}{|l|}{ Anemia status } \\
\hline Not anemia $(\mathrm{Hb}$ & $24(60.0)$ & $21(52.5)$ & $20(50.0)$ & $65(54.2)$ \\
\hline $11.0-14.0 \mathrm{~g} / \mathrm{dl})$ & $16(40.0)$ & $19(47.5)$ & $20(50.0)$ & $55(45.8)$ \\
\hline $\begin{array}{l}\text { Anemia }(\mathrm{Hb}<11.0 \\
\mathrm{g} / \mathrm{dl})\end{array}$ & & & & \\
\hline
\end{tabular}

increased in MMS group (1.8). For participants aged 20-35, the highest increased in MMS + Fe group (1.1) (Table 2).

Table 2: Average hemoglobin levels based on respondent's age

\begin{tabular}{|c|c|c|c|c|}
\hline \multirow[t]{3}{*}{ Group intervention } & \multicolumn{4}{|c|}{ Hemoglobin (Mean \pm SD) } \\
\hline & \multicolumn{2}{|c|}{$<20$ and $>35$ years } & \multicolumn{2}{|l|}{$20-35$ years } \\
\hline & before & After & Before & After \\
\hline Fe tablets & $10.3 \pm 0.40$ & $10.7 \pm 0.38$ & $10.8 \pm 0.67$ & $11.1 \pm 0.53$ \\
\hline MMS & $10.0 \pm 0.47$ & $11.8 \pm 0.60$ & $10.8 \pm 0.67$ & $11.6 \pm 0.49$ \\
\hline Fe tablets+MMS & $10.7 \pm 0.45$ & $11.9 \pm 0.51$ & $10.9 \pm 0.55$ & $12.0 \pm 0.49$ \\
\hline
\end{tabular}

The $\mathrm{Hb}$ levels in $\mathrm{Fe}$ tablet, MMS, and MMS + Fe table groups were significantly increased $(p<0.001)$ after the intervention given $(0.4,0.8$, and 1.1 , respectively). The lowest percentage was in the Fe group $(3.7 \%)$, while the highest was in the MMS + Fe group (10.1\%). The result shows that the administration of Fe tablets, MMS, and the combination of Fe tablets and MMS for 90 days can increase the $\mathrm{Hb}$ levels of pregnant women (Table 3 ).

Table 3: Average $\mathrm{Hb}$ levels before and after intervention

\begin{tabular}{llll}
\hline Hb level & \multicolumn{2}{l}{ Group intervention (Mean \pm SD) } \\
\cline { 2 - 4 } & Fe tablets & MMS & Fe tablets+MMS \\
\hline Before & $10.7 \pm 0.66$ & $10.8 \pm 0.66$ & $10.9 \pm 0.53$ \\
After & $11.1 \pm 0.53$ & $11.6 \pm 0.50$ & $12.0 \pm 0.49$ \\
P value & $0.000^{*}$ & $0.000^{*}$ & $0.000^{*}$ \\
$\Delta$ Hb levels & $0.4 \pm 0.31$ & $0.8 \pm 0.37$ & $1.1 \pm 0.30$ \\
$\% \Delta$ & $3.7 \uparrow$ & $7.4 \uparrow$ & $10.1 \uparrow$ \\
\hline * $\Delta$ raired &
\end{tabular}

The one-way ANOVA test shows that there was a significant different of $\mathrm{Hb}$ changes among groups after the intervention $(p<0.001)$ (Table 4).

\section{Discussion}

The respondents who had the highest level of intervention were pregnant women who were not high risk (aged 20-35 years), had an elementary school education, worked as housewives, and were not anemic. 20-35 years can be considered to be a productive age for pregnant women. The age factor affects the incidence of anemia because, at the age 
Table 4: Differences in $\mathrm{Hb}$ levels between intervention groups

\begin{tabular}{lllll}
\hline Variables & \multicolumn{2}{l}{ Groups } & $\mathrm{p}$ \\
\cline { 2 - 4 } & Fe tablets & MMS & Fe tablets+MMS & \\
\hline Hb levels before intervention & 9.5 & 9.2 & 9.7 & $0.388^{*}$ \\
$\quad$ Minimum & 12.4 & 11.8 & 11.8 & \\
$\quad$ Maximum & & & & $<0.001^{*}$ \\
Hb levels after intervention & 10.0 & 10.8 & 11.0 & \\
$\quad$ Minimum & 12.7 & 12.7 & 12.8 & $<0.001^{*}$ \\
$\quad$ Maximum & -1.0 & $-1.7-0.3$ & $-1.8-0.5$ & \\
$\begin{array}{l}\Delta \text { Hb levels } \\
\quad \text { Minimum }\end{array}$ & 1.0 & & & \\
$\quad$ Maximum & & & \\
\hline *One-way ANOVA test. MMS: Multi-micronutrient supplement. & & & &
\end{tabular}

of 20 and 35 years, women are more stable in paying attention to the fulfillment of their need for iron [7], [8]. An increase in $\mathrm{Hb}$ levels has been found to coincide with increasing age [9]. It was also found that, as Alam et al. (2021) reported, Hb levels are influenced by age, occupation, and family income.

A factor that indirectly affects the maternal mortality rate is the work of pregnant women. Access to sufficient information helps pregnant women who work in the formal sector to obtain important health information. The environment can also influence a person's ability and willingness to gain experience and knowledge, either directly or indirectly [10]. Employment in pregnant women can increase both income and reproductive health status, due to their ability to obtain new knowledge through discussions and interactions with other people [11].

More than half of the pregnant women who participated in this study did not experience anemia. The remainder of the women demonstrated the need for supplementation of Fe tablets and other supplements in the form of MMSs. MMSs are supplements that were developed for pregnant women. In the Banggai and Probolinggo regions, cooperation with international NGO led to important research being conducted [12]. Based on the results of the study, the increase in $\mathrm{Hb}$ levels due to taking MMS was higher than that due to taking Fe tablets.

Multi-micronutrient supplements (MMSs) are a charitable organization that provides nutritional support to millions of people living in at-risk and underserved communities in 50 countries around the world. MMSs, as a charity, provide supplements for pregnant women, facilitate safe births, support the health of babies, and provide Vitamin A and other supplements for children up to the age of 5 [13].

The results showed differences in $\mathrm{Hb}$ levels before and after the interventions, which included $\mathrm{Fe}$ tablets, MMSs, and a combination of both. The highest increase was found in the combination of MMSs and Fe tablets.

The mechanism of iron absorption in the body begins with the luminal phase in the stomach. The iron will be processed in the stomach through the stomach acid breaking of its bonds with other compounds. Then, there is a reduction from the form of iron $\left(\mathrm{Fe}^{3+}\right)$ to iron $\left(\mathrm{Fe}^{2+}\right)$, which can be absorbed in the duodenum.
Furthermore, the mucosal phase, or iron absorption in the intestine, occurs in the duodenum and jejunum. Iron from food sources enters in the form of iron $\left(\mathrm{Fe}^{3+}\right)$ or non-heme iron, while the iron is absorbed as iron $\left(\mathrm{Fe}^{2+}\right)$. The absorption of iron is then stored in the cytoplasm [14], [15].

This study is in line with what was reported by Sari (2021). The average $\mathrm{Hb}$ level in pregnant women was higher after consuming $\mathrm{Fe}$ tablets $(21.68 \mathrm{mg} / \mathrm{ml} \pm 10.61)$ compared to those who had not taken tablets $(17.29 \mathrm{mg} / \mathrm{ml} \pm 9.90)$. This showed that there was a significant difference in $\mathrm{Hb}$ levels in pregnant women before and after taking Fe tablets ( $p=0.014)$. This led to the government's recommendation and program to provide support for pregnant women to take Fe tablets.

Through government programs, pregnant women are required to consume a total of $90 \mathrm{Fe}$ tablets during pregnancy. The absorption of $\mathrm{Fe}$ tablets is influenced by numerous factors, including diseases that affect women during pregnancy and the consumption of Vitamin C, which can help the body to absorb Fe from food. Some foods reduce the ability to absorb Fe such as tea, coffee, calcium-containing foods, and other dairy products [16]

Iron supplementation in pregnant women who are not anemic but have low ferritin levels can be useful for the prevention of iron deficiency anemia. The average ferritin level increased after taking iron tablets. In addition, serum ferritin levels were lowest in pregnant women with severe anemia. Deficiency of Fe supplementation is the cause of anemia in women and pregnant women, so giving $\mathrm{Fe}$ supplements to pregnant women are a commonly used health measure. Regular iron supplementation can prevent anemia and is selective for women with, or at risk of developing, iron deficiency anemia [17].

The MMS intervention was successful in preventing anemia in pregnant women. This study showed that there were differences in $\mathrm{Hb}$ levels before and after all three interventions, which were given for 90 days and were effective for the prevention of anemia during pregnancy. The early development of the placenta and fetal growth requires iron (Fe). Adequate and appropriate iron intake can prevent malnutrition and iron deficiency [18]. Smith et al. (2017) reported that the MMS intervention could reduce the rate of anemia in pregnant women by $29 \%$, reduce the risk of infant mortality (0-6 months of age), reduce the risk of stillbirth by $8 \%$, and reduce the risk of anemic pregnant women by $26 \%$. In line with what was reported by Keats, Haider, Tam, and Bhutta (2019), MMS can reduce the risk of children being born with low birth weight by $12 \%$, children being born prematurely by $8 \%$, and the risk of being underweight for pregnant women by $16 \%$.

The increase in $\mathrm{Hb}$ levels, which constitutes the level of red blood cells in pregnant women, is very helpful in the labor process. This is in line with 
the research of Hasswane et al. (2015) in Morocco, which stated that the risk factor for anemia, or lack of red blood cells, was focused on the delivery period. About $82 \%$ of pregnant women had no problems during delivery because of a large amount of blood, $57.6 \%$ due to moderate blood, and a small percentage of $0.8 \%$ due to low blood. A study conducted in South and North Rwanda showed that iron deficiency may cause anemia in $30.9 \%$ of youth and $11 \%$ of women [19], [20].

Proper access to the health services is important for pregnant women to monitor their health outcomes, including $\mathrm{Hb}$. With regular visit to the health services, the mothers can also get Fe supplement that is probably essential to maintain their $\mathrm{Hb}$ levels.

Moreover, preparing the women earlier, before their pregnancy, may be better to maintain better women's $\mathrm{Hb}$ level. Thus, $\mathrm{Hb}$ monitoring should begin since before conception, and continue to pregnancy, and during childbirth. Public health partnerships are an important link in the continuous care of pregnant women. Good quality antenatal care, the presence of skilled health workers during delivery, and the provision of postpartum care for mothers and newborns are very important in reducing maternal and newborn mortality [20], [21], [22]. Research shows that the main factors associated with the prevention of anemia in pregnant women include systematic screening for anemia in postpartum and more screening during early pregnancy [20].

Hepi Gita's research (2019) showed that most $(95.0 \%)$ of the 20 respondents with low $\mathrm{Hb}$ levels respondents had a low level of iron consumption, while most $(79.6 \%)$ of the 49 respondents with normal $\mathrm{Hb}$ levels had a low level of iron consumption. From the results of the cross-tabulation, no trend was found between the level of iron consumption and the level of $\mathrm{Hb}$. The absence of a relationship between the level of iron consumption and $\mathrm{Hb}$ levels in the study occurs as low $\mathrm{Hb}$ levels are not only caused by iron deficiency but can also occur due to deficiencies in folic acid, Vitamin A, Vitamin B12, riboflavin, and Vitamin B6, which functions to produce red blood cells in the bone marrow [23].

The intervention of MMS combined with $\mathrm{Fe}$ tablets showed the highest increase in $\mathrm{Hb}$ levels in pregnant women, with a significant effect on $\mathrm{Hb}$ levels. In line with the research of Bourassa et al. (2019), a healthy pregnancy requires an adequate intake of major micronutrients (such as Vitamins A, D, E, B6, folic acid, B12, and $\mathrm{C}$, and the minerals iron, zinc, iodine, copper, and selenium) to accommodate the needs of both the mother and the fetus. Micronutrient deficiency during pregnancy can have direct long-term impacts, namely, maternal mortality, miscarriage, low birth weight, infant mortality, stunting, and an increased risk of impaired cognitive development. Overcoming vitamin and mineral deficiencies require micronutrient supplementation (MMSs) to reduce risks during pregnancy and childbirth [24], [25].

\section{Conclusion}

The average change in $\mathrm{Hb}$ levels in the intervention group with $\mathrm{Fe}$ tablets was $0.4 \mathrm{~g} / \mathrm{dL}$, while the intervention for MMS was $0.8 \mathrm{~g} / \mathrm{dL}$, with differences in the $\mathrm{Hb}$ levels of pregnant women with Fe tablet intervention $(p=0.000)$ and multi-supplement intervention $(p=0.000)$. This means that the intervention of Fe tablets and MMSs significantly affected the $\mathrm{Hb}$ levels of pregnant women.

\section{References}

1. IImi IM, Arini FA, Novriyanti D. Torbangun leaf snack bar: An alternative source for iron and calcium for breastfeeding mothers in post-disaster refugee camp. Indones $\mathrm{J}$ Nutr Sci. 2021;1(1):157.

2. Siti I, Siahaan S, Wanggae G, Widyasari R, Kurniawan A Aryastami NK, Pratiwi NL. dinamika jender terhadap akses pelayanan kesehatan maternal sembilan etnis di Indonesia. Bulet Penelitian Sistem Kesehatan. 2019;22(1):1-9.

3. Tarigan DF, Andriani F. Hubungan paritas dengan kejadian retensio plasenta di rumah sakit umum daerah $\mathrm{H}$. Abdul manan simatupang kisaran kabupaten asahan tahun 2019. J Gentle Birth. 2020;3(1):12-8.

4. Pamungkas CE, Amini A. Refreshing penyuluhan tanda-tanda bahaya kehamilan menggunakan buku kia pada kelas ibu hamil di wilayah kerja puskesmas karang Pule. J Pengabdian Masyarakat Kebidanan. 2020;2(1):23-30.

5. Sakung JM, Sirajuddin S, Zulkifli A, Rahman SA, Palutturi S. The effect of chayote (sechium edule) on blood glucose level of high school teachers of pre-diabetes. Executive Editor 2018;9(5):245.

6. Lee JE, Lee J, Lee H, Park JK, Park Y, Choi WS. End-of-life care needs for noncancer patients who want to die at home in South Korea. Int J Nurs Pract 2020;26(2):e12808. https://doi. org/10.1111/ijn.12808

PMid:31975562

7. Mirza FG, Abdul-Kadir R, Breymann C, Fraser IS, Taher A. Impact and management of iron deficiency and iron deficiency anemia in women's health. Expert Rev Hematolol. 2018;119:727-36. https://doi.org/10.1080/17474086.2018.1502081

PMid:30019973

8. Dziembowska I, Kwapisz J, Izdebski P, Żekanowska E. Mild iron deficiency may affect female endurance and behavior. Physiol Behav. 2019;205:44-50.

9. Accinelli RA, Leon-Abarca JA. Age and altitude of residence determine anemia prevalence in Peruvian 6 to 35 months old children. PLoS One. 2020;15(1):e0226846. https://doi. org/10.1371/journal.pone.0226846 PMid:31940318

10. Alam F, Khanum S, Jahan I, Ahmed JU. Prevalence and sociodemographic factors responsible for anaemia in pregnancy: Experience in a military hospital in Bangladesh. BIRDEM Med J. 2021;11(1):52-6.

11. Gammage S, Sultana N, Glinski A. Reducing vulnerable employment: Is there a role for reproductive health, social protection, and labor market policy? Feminist Econ. 2020;26(1):121-53. 
12. Hurley $\mathrm{K}$, Achadi EL, Ajello $\mathrm{C}$, Askari $\mathrm{S}$, Bajoria $\mathrm{M}$, Beesabathuni $\mathrm{K}$, et al. Prevention of child wasting in Asia: Possible role for multiple micronutrient supplementation in pregnancy. Field Exchange 2020;63:76.

13. Horino M, Bahar M, Al-Jawaldeh A, Seita A, Hurley K, Kraemer K, et al. Antenatal multiple micronutrient supplementation in the state of palestine: A protocol for implementation and evaluation. Curr Dev Nutr. 2021;5(2):1316-6.

14. Lopez A, Cacoub P, Macdougall IC, Peyrin-Biroulet L. Iron deficiency anaemia. Lancet. 2016;387(10021):907-16. https:// doi.org/10.1016/S0140-6736(15)60865-0

15. Handayani KD, Widyawati MN. The effect of combination alkaline water and iron tablets on improving hemoglobin level among adolescent. Int J Nurs Health Serv. 2020;3(5):615-21.

16. Sari AP. The Effectiveness of Iron Tablets Consumption in Pregnant Women to Ferritin Levels in llir Timur I Palembang. Netherlands: Atlantis Press; 2021. p. 5-8.

17. Gulo NS, Anuhgerah DE, Handayani D. Efektivitas tablet zat besi terhadap perubahan tekanan darah ibu hamil. J Kebidanan Kestra. 2021;3(2):149-57.

18. Zehra A, Abdullah SM, Saboor M. Effect of intravenous iron supplementation on hepcidin levels in iron deficient pregnant females in second and third trimester. Indian $\mathrm{J}$ Hematol Blood Transf. 2017;33(3):396-401. https://doi.org/10.1007/ s12288-016-0736-1

PMid:28824243

19. Donahue Angel M, Berti P, Siekmans K, Tugirimana PL, Boy E. Prevalence of iron deficiency and iron deficiency anemia in the northern and southern provinces of Rwanda. Food Nutr Bull. 2017;38(4):554-63. https://doi.org/10.1177/0379572117723134 PMid:28826251
20. Hasswane N, Bouziane A, Mrabet M, Laamiri FZ, Aguenaou H, Barkat A. Prevalence and factors associated with anemia pregnancy in a group of Moroccan pregnant women. J Biosci Med. 2015;3(10):88.

21. Skania PC, Dasuki D, Utami FS. The effect of fe tablet consumption on hemoglobin $(\mathrm{Hb})$ increase in pregnant women: A systematic literature review. J Kebidanan Midwiferia. 2020;6(2):8-13.

22. Smith ER, Shankar AH, Wu LS, Aboud S, Adu-Afarwuah S, Ali $\mathrm{H}$, et al. Modifiers of the effect of maternal multiple micronutrient supplementation on stillbirth, birth outcomes, and infant mortality: A meta-analysis of individual patient data from 17 randomised trials in low-income and middle-income countries. Lancet Global Health. 2017;5(11):e1090-100. https:// doi.org/10.1016/S2214-109X(17)30371-6 PMid:29025632

23. Hepi Gita K. Hubungan Tingkat Konsumsi Protein, Zat Besi dan Kadar Hemoglobin dengan Produktivitas Kerja Tenaga Kerja Wanita di PT. Indonesia: Akar Wangi Gianyar. Poltekkes Denpasar, Denpasar; 2019.

24. Bourassa MW, Osendarp SJ, Adu-Afarwuah S, Ahmed S, Ajello $C$, Bergeron $\mathrm{G}$, et al. Review of the evidence regarding the use of antenatal multiple micronutrient supplementation in lowand middle-income countries. Ann N Y Acad Sci 2019;1444(1):6. https://doi.org/10.1111/nyas.14121

PMid:31134643

25. Keats EC, Haider BA, Tam E, Bhutta ZA. Multiple-micronutrient supplementation for women during pregnancy. Cochrane Database Syst Rev 2019;3(3):CD004905. https://doi. org/10.1002/14651858.CD004905.pub6

PMid:30873598 